\title{
TRADITIONS OF REFORM IN U.S. TEACHER EDUCATION
}

\author{
Kenneth M. Zeichner and Daniel P. Liston ${ }^{1}$
}

\begin{abstract}
A tradition is an argument extended through time in which certain fundamental agreements are defined and redefined in terms of two kinds of conflict: those with critics and enemies external to the tradition who reject all or at least key parts of those fundamental agreements, and those internal, interpretative debates through which the meaning and rationale of the fundamental agreements come to be expressed and by whose progress a tradition is constituted. . . . To appeal to tradition is to insist that we cannot adequately identify either our own commitments or those of others in the argumentative conflicts of the present except by situating them within these historics which made them what they have now become. (MacIntyre, 1988, pp. 12-13)
\end{abstract}

One of the most notable characteristics of the current reform movement in U.S. teacher education is its lack of historical consciousness. Very little attention has been given in the literature of this movement to the historical roots of contemporary reform proposals. One is hard pressed to find explicit references in this literature to any of the numerous reform efforts which have been initiated by foundations, governmental agencies, or by teacher educators themselves over the past 50 years. ${ }^{2}$ Although there have been several recent analyses of the development of teacher education programs within colleges and universities in the 20th century which have illuminated many of the tensions and conflicts impeding the reform of programs (Clifford and Guthrie, 1988; Herbst, 1989; Powell, 1976; Schneider, 1987), attempts to identify lessons that have been learned from specific teacher education reform efforts, and from similar efforts in other professions, that could be instructive to contemporary reformers, are scarce.

One consequence of this historical amnesia in the current teacher education reform movement is a lack of clarity with regard to the theoretical and political commitments underlying specific reform proposals. Currently popular terms like "reflective teaching," "action research," "subject matter,"

\footnotetext{
${ }^{1}$ Kenneth M. Zeichner, professor in the Department of Curriculum and Instruction, University of Wisconsin-Madison, is a senior researcher with the National Center for Research on Teacher Education. Daniel P. Liston is an assistant professor in the Department of Education, Washington University, St. Louis.

${ }^{2}$ Examples of reform efforts that are rarely mentioned in the current reform literature include the National Teacher Corps (Smith, 1980); TTT (Provus, 1975); and M.A.T. programs (Coley and Thorpe, 1986).

${ }^{3}$ Some examples of recent efforts to inform the current reform debate through analyses of reform projects of the past include Sykes (1984); Coley and Thorpe (1986); Johnson, (1987); Zeichner (1988); and Herbst, 1989.
} 
"development," and "empowerment" are bandied about in the teacher education community with a great deal of confusion about the underlying commitments and assumptions which distinguish one approach from another. In some cases, (e.g., "reflective teaching") the use of particular terms has become almost meaningless because of the way in which teacher educators holding very diverse perspectives have expressed allegiance to the same slogans.

It is our contention that efforts to reform teacher education throughout the 20th century have always reflected, often implicitly, varying degrees of commitment and affiliation to several distinct reform traditions. Drawing on Kliebard's (1986) analysis of the various interest groups that have vied for control of the primary and secondary school curriculum in this century and on several recent analyses of alternative conceptual orientations in teacher education (Feiman-Nemser, in press; Joyce, 1975; Kirk, 1986; and Zeichner, 1983), we will outline and discuss four distinct traditions of reform in twentieth century U.S. teacher education. ${ }^{4}$ These traditions are (a) the academic tradition, (b) the social efficiency tradition, (c) the developmentalist tradition, and (d) the social reconstructionist tradition. We believe that this framework of reform traditions can potentially help clarify some of the important differences among contemporary reform proposals that on the surface appear to be similar. Following the presentation of the reform traditions, we will briefly illustrate the heuristic value of the framework with a discussion of current proposals regarding "reflective teaching" and will discuss the ways in which we feel this framework can stimulate needed debate within and across reform traditions about the purposes and goals of teacher education in relation to individuals, schooling, and society.

Although we do not advocate here in favor of any single reform tradition, we do argue that it is important for teacher educators to understand the conceptions of knowledge, teaching, learning, and social welfare associated with particular reform proposals. The implication is that teacher educators should choose carefully among reform alternatives with a clear sense of their own location in relation to the four reform traditions.

\footnotetext{
${ }^{4} \mathrm{~A}$ more elaborated analysis of these traditions can be found in Chapter I of Liston and Zeichner (in press).
} 


\section{The Academic Tradition}

Prior to the existence of formal programs of teacher education, a classical liberal arts education was equivalent to being prepared to teach (Borrowman, 1965). During the 20th century, as programs for the preparation of elementary and secondary teachers became established in colleges and universities, the point of view persisted that a sound liberal arts education, complemented by an apprenticeship experience in a school, is the most sensible way to prepare teachers for their work. Throughout this period, the contributions of schools, colleges, and departments of education to an education for teaching (with the exception of student teaching) were severely criticized for their alleged inferior intellectual quality and for interfering with the liberal education of teachers. This orientation to teacher education emphasizes the teacher's role as a scholar and subject matter specialist and has taken different forms, depending upon the particular view of the disciplines and subject matter knowledge that has supported specific reform proposals.

One of the earliest critics of professional Education courses for prospective teachers was Abraham Flexner, noted for his contributions to the reform of medical education in the United States. In his seminal work on European and American universities, Flexner (1930) lodged a number of criticisms which have been raised repeatedly by advocates of the academic tradition. He argued for example, that the mastery of subject matter is the most important thing in the education of a teacher and that Education courses interfere with this fundamental goal. Flexner, like many who were to follow him, criticized Education courses for their intellectual superficiality, Education professors and their students for their meager intellectual resources, and Education scholarship for its insignificance. Accepting the value of a few legitimate areas of study in Education such as educational philosophy, and comparative educational studies, Flexner argued that all of the rest of what teachers need to learn, beyond a sound liberal education, could come from an apprenticeship experience in a school.

Why should not an educated person, broadly and deeply versed in educational philosophy and experience, help himself from that point on? Why should his attention be diverted during these pregnant years to the trivialities and applications with which common sense can deal adequately when the time comes? (pp. 99-100)

Flexner (1930) complained that it took 26 pages alone to list the names of the staff at Teachers College, Columbia, and that most of the 200 pages of course listings in the Teachers College catalog were devoted to "trivial, obvious, and inconsequential subjects, which could safely be left to the common sense or intelligence of any fairly educated person" (p. 100). Flexner's bias toward disciplinary knowledge is also revealed in his criticisms of the Education literature.

The topics discussed in the current literature are so unimportant as compared with the 
subjects discussed by physicists, chemists, or political scientists that it may well seem as though they were designed to frighten off intelligence. (p. 102)

Since Flexner's critique, a number of highly visible and controversial analyses of teacher education have articulated these same themes: the alleged inferior intellectual quality of Education courses, faculty, and students. Among these are those by Lynd (1953); Bestor (1953, 1956); Koerner (1963); and Conant (1963). ${ }^{5}$ There is little doubt that at least some of the charges leveled by these academic reformers of teacher education have been and continue to be true in some situations. There is some question however, as to the extent to which these caricatures of the professional education component of teacher education are representative of practice generally or exclusively (see Zeichner, 1988a). Recently, several commentators have argued (e.g., Clifford and Gutherie, 1988; Ginsburg, 1988; Lanier, 1986) that these academically oriented criticisms may have less to do with the actual quality of people, courses, and programs, than with a status based on gender and social class differences between Education faculty and students and those in the arts and sciences. Although even the harshest of these critics, such as Bestor, admit that things are not all well within courses in the arts and sciences, the general assumption has seemed to be that courses within the arts and sciences are necessarily liberalizing while Education courses are exclusively technical and vocational in the narrowest sense (Borrowman, 1956).

The programmatic implications of this academic tradition have changed somewhat over time depending upon particular views of a good liberal education and of the particular kinds of subject matter knowledge needed by teachers. Following the decline of the humanist position based firmly in a classical liberal arts education (Kliebard, 1986) and periodic attempts to professionalize subject matter offerings by considering the pedagogical implications of academic courses (Borrowman, 1956), most manifestations of this position until recently, have involved proposals for the preparation of teachers based firmly in the traditional academic disciplines as they are taught to all students regardless of their intended vocations. It has been repeatedly argued that this approach will draw many academically talented students into teaching who would otherwise be repelled by requirements to take many Education courses of doubtful intellectual value. Bestor (1953) succinctly summarizes this position regarding the most appropriate teacher education program as follows:

A new curriculum for the education of teachers, based firmly upon the liberal arts and sciences, rather than upon the mere vocational skills of pedagogy will do more to restore the repute of the public schools than any other step that can be taken. Not only will

\footnotetext{
${ }^{5}$ See Cohen (1976) for a discussion of this same debate within the field of history. See Zeichner (1988a) for an analysis and critique of these four academically oriented reform proposals.
} 
teachers be adequately trained in the disciplines they undertake to teach, they will also be imbued with respect for those disciplines and will be prepared to resist the antiintellectualism that currently threatens the schools. And when the tide begins to turn, young men and young women of genuine intellectual interest and capacity will be attracted in increasing numbers to the profession of public school teaching. They will not be repelled at the outset by being asked to lay aside their intellectual interests and fritter away their time in courses of the pedagogues. (p. 147)

Until very recently, the academic tradition of reform in teacher education has had the most impact on the preparation of secondary teachers. With a few notable exceptions such as in the state of California (Hendrick, 1967) and in liberal arts colleges (Travers and Sacks, 1987), elementary education students have typically completed twice as many Education courses as prospective secondary teachers and have rarely completed full academic majors. One notable example of academically oriented teacher education reforms was the efforts of the Ford Foundation and its Fund For the Advancement of Education to establish the dominance of various forms of graduate teacher education as a replacement for traditional forms of undergraduate preparation. In the 1950s and 1960s Ford sponsored several different kinds of graduate teacher education program models, including an attempt to convert an entire state (Arkansas) to an approach in which all prospective teachers would receive a full four years of liberal arts education as undergraduates and a reduced load of professional education courses at the graduate level. Throughout this period, Ford spent over $\$ 70$ million on initiatives that included fifthyear preparation programs specializing in the preparation of older liberal arts graduates for teaching, M.A.T. programs for secondary teachers that were jointly developed by Education and arts and sciences faculties, and a special set of "Breakthrough" programs (Stone, 1968; Woodring, 1957). These Ford programs became models for many other graduate programs across the United States some of which continue to exist today, as well as for significant aspects of the National Teacher Corps (Corwin, 1973; Saxe, 1965).

Recently many challenges have been raised concerning this emphasis on the importance of a traditionally defined liberal arts education and of subject matter knowledge for teachers. One line of inquiry from a feminist perspective, criticizes a traditionally defined liberal arts education for perpetuating the Platonic emphasis "on mind not head, thought not action, production not reproduction, and reason not emotion" (Martin, 1987, p. 406):

The project for teacher educators that I am recommending . . . is neither so simplistic nor so impoverished as one that merely replaces an emphasis on head with one on hand, one on thought with one on action, one on reason with one on feeling and emotion, one on separation of the self with one on connection to others, one on the productive processes of society with one on its reproductive processes. It is a difficult project to carry out 
because it is possible to join together the two sides of the various Platonic dichotomies only if they are equally valued.... Once we understand the historic roots of liberal education, we will begin to see the inappropriateness for prospective teachers today of the educational ideal Plato held up for the guardians of his just state and of the educational program he designed for them in light of it. (p. 406)

One contemporary example of a teacher education program that appears to have been influenced by recent feminist scholarship is the graduate M.A.T. program at Lewis and Clark College (Tetreault, 1987). Here teacher educators claim to have infused issues on women and gender that challenge Platonic dichotomies throughout the curriculum and have critiqued the pedagogy and social relations in their program through lenses provided by feminist scholarship.

A second challenge to the dominance of conventional notions within the academic reform tradition has emerged from recent work on teachers' subject matter knowledge. Here, stimulated in part by Shulman's $(1986,1987)$ criticisms of the lack of attention to teachers' subject matter understandings by both researchers and teacher educators, investigators are exploring how teachers' understandings of subject matter content interact with other kinds of knowledge (e.g., "pedagogical content knowledge") to influence the instruction that is provided to pupils (e.g., Ball and McDiarmid, 1990; Wilson, Shulman, and Richert, 1987). One consequence of these efforts by cognitive psychologists and others to explicate the dimensions of subject matter knowledge that are appropriate in a teacher's education is the emergence of a new "knowledge base" for teacher education that is much broader than the earlier behavioristic knowledge bases of the 1960s and 1970s (see Reynolds, 1989).

Feiman-Nemser (1990) describes one contemporary example of how this cognitive psychological perspective has been applied to teacher education in the Academic Learning Program at Michigan State University. This program is primarily concerned with preparing elementary and secondary teachers to teach school subjects in ways that promote conceptual understanding (Schram, Wilcox, Lanier, and Lappan 1988). Another contemporary example of this general approach is the work on "cognitively guided instruction" that has been introduced into teacher education programs at the University of Wisconsin-Madison (Fennema, Carpenter, and Peterson, in press). In courses incorporating a "CGI" orientation, prospective teachers are given opportunities to understand how children think about mathematics and then to base their instruction on children's cognitions and knowledge. The goal for the CGI program is to prepare teachers who can facilitate children's active mental involvement in worthwhile mathematical tasks.

A third challenge to historically dominant notions of academically oriented reform in teacher education has focused on the Western, white, middle class biases in the liberal arts curriculum that have led to an absence of non-Western and culturally diverse perspectives in the education of U.S. teachers. There has also been criticism of the failure of many academically oriented teacher education reforms 
(e.g., M.A.T. programs) to respond to needs for preparing teachers to work in our economically depressed and culturally diverse inner cities (Coley and Thorpe, 1986; Keppel, 1986; Zeichner, 1988b).

One response to these elitist tendencies in U.S. teacher education has been attempts to incorporate multicultural perspectives into the curricula of teacher education programs (Gay, 1986). This movement, which received a great deal of federal support in the 1960s and 1970s through Teacher Corps and Teachers Training Teachers (TTT) programs (Drummond and Andrews, 1980), addressed issues relating to the preparation of teachers for the culturally and racially diverse society in which we live, and to teaching in particular schools dominated by poor pupils and pupils of color. A great deal of effort has been devoted over the years to analyzing the extent to which multicultural perspectives have been incorporated into the curricula of U.S. teacher education programs (e.g., Gollnick, 1978), in assessing the impact of multicultural learning opportunities which have been incorporated into programs (e.g., Grant and Koskella, 1986) and in providing guidelines for action and program exemplars to the teacher education community (e.g., Baptiste, Baptiste, and Gollnick, 1980). Cabello and Dash (1988) and Grant and Secada (1990) discuss recent efforts to develop teacher education programs with a focus on pupil diversity.

Despite these challenges to historically dominant notions of a good liberal education for teachers, recent state policies such as the ones placing limits on the number of Education courses allowed in a teacher education program (e.g., Imig, 1986) and the establishment of alternate routes allowing people to enter teaching with little or no professional education course work (Uhler, 1987) reinforce the unfortunate confusion noted by Borrowman (1956) that a course is necessarily liberalizing if offered by academic faculty and is necessarily technical if offered in a School of Education. Current efforts to arbitrarily limit the number of Education courses in a teacher preparation program fail to address the issue of academic quality at all by ignoring the substance of what is offered within particular courses (Zeichner, 1988a). Calls for a return to traditional forms of a liberal arts education for teachers that continue today (e.g., Damerell, 1985) are unresponsive to the challenges which have been raised by all three groups of critics.

\section{The Social Efficiency Tradition}

A second major reform tradition in 20th century U.S. teacher education, the social efficiency tradition, has involved a faith in the power of science to provide the basis for building a teacher education curriculum. This tradition has emerged largely within schools, departments, and colleges of Education and has been seen by many as part of a strategy to strengthen the educationists' claim to legitimacy within the university (Sykes, 1984). Cremin (1953), in reflecting upon the development of teacher education in the early part of this century, observed: 
Growing out of this faith (in science) came innumerable attempts during the 1920's to break down and analyze the teaching task into its component parts and to build a teacher education program around such technical analysis. (p. 246)

One of the earliest and most prominent efforts at scientific curriculum making in U.S. teacher education was the Commonwealth Teacher Training Study (Charters and Waples, 1929). Criticizing existing teacher education programs for lacking a clear definition of objectives and logical plans of procedure, Charters and Waples sought to demonstrate that a comprehensive description of the duties and traits of teachers would provide the necessary basis for systematically determining what teachers should be taught. Kliebard (1975) summarizes the way in which the study was conducted:

As a first step Charters and Waples ascertained the traits that characterize excellent teachers. Adapting the consensus approach, the investigators used two methods: analyzing the professional literature and interviewing expert judges. Working from a list of 83 traits, ranging alphabetically from Accuracy through Foresight and Magnetism all the way to Wittiness, "translators" were given the task of interpreting statements made in writing or in interviews. Reliability among translators was determined by applying the Spearman prophecy formula. Finally, after some of the original traits were telescoped, scientifically determined lists were prepared indicating that senior high school teachers should be characterized by twenty-six traits including Good Taste and Propriety; junior high school teachers by Conventionality (morality) and Openmindedness. . . . Next in an adaptation of the job analysis technique, the investigators collected a master list of 1,001 teacher activities. (p. 35)

The teacher activities were based on the results of mailing surveys to experienced teachers in 42 states. The final list of 1,001 teaching activities was subdivided into seven major divisions (e.g., classroom instruction, school and classroom management). These teaching activities and the master list of 83 teacher traits broken down into those appropriate for various levels of schooling were to assist teacher educators in designing teacher preparation programs that were based firmly in the realities of schooling rather than in tradition or individual judgment. Although this study had little direct impact on teacher education programs, the idea of systematically building a curriculum of teacher education on the basis of a careful analysis of the work performed by teachers persisted.

One of the subsequent manifestations of this perspective in U.S. teacher education was the emergence of Competency/Performance Based Teacher Education (C/PBTE) in the 1960s and 1970s. Stimulated in part by applications of behavioral psychology to the training of personnel in industry and the military during and after World War II (McDonald, 1973), and by the U.S. Department of Education's support for the development of plans for nine model competency-based teacher education programs which applied procedures of systems and job analysis to the design of a teacher education 
curriculum (Clarke, 1969), the idea of C/PBTE received so much attention in the literature that it has been described both within the United States and abroad (Atkin and Raths, 1974; Turney, 1977) as the single most influential and controversial trend in U.S. teacher education in this century.

Despite all of the attention that C/PBTE received in the literature and popular press, actual practice in teacher education programs was affected by the movement only minimally. Sandefur and Nicklas (1981) concluded for example, that full-scale implementation of C/PBTE programs occurred in only about 13 percent of the 1200 or so institutions associated with the American Association of Colleges of Teacher Education. Joyce, Yarger, and Howey (1977) and the National Center for Education Statistics (1977) reached similar conclusions in two national surveys of practices in preservice teacher education programs. Two of the most prominent examples of institutions where C/PBTE did gain a foothold were the University of Houston (Ginsburg, 1988) and the University of Toledo (Howey and Zimpher, 1989).

This general approach to teacher education emphasizes the acquisition of specific and observable skills of teaching which are assumed to be related to pupil learning. By the 1960s educational research methodology had progressed far beyond the relatively crude survey and analysis techniques used in the Commonwealth Study. This more recent version of the social efficiency orientation sought to establish the intellectual legitimacy of teacher education through a grounding in classroom research linking observable teacher behaviors with pupil outcomes. Despite this increased sophistication in research methods, one of the major criticisms of the approach has been a questioning of the empirical validity of the teaching competencies (e.g., Heath and Nielson, 1974; Tom, 1984). Even advocates of the approach were careful to admit that they had not yet attained their goal of empirically validated teaching competencies. They hoped however, that increased commitment to the approach from the profession and from those who would support the necessary research would yield such knowledge eventually (Sykes, 1984).

One of the key characteristics of the C/PBTE approach is that the knowledge and skills to be mastered by prospective teachers are specified in advance, usually in behavioral terms. Furthermore, the criteria by which successful mastery is to be measured are made explicit. Performance, rather than the completion of specified course work is assumed to be the most valid measure of teaching competence (Gage and Winne, 1975). Another important element in this approach is the development of instructional, management, and evaluation systems to monitor students' mastery of individual competencies. A number of significant developments occurred in this area. First, microteaching was developed at Stanford University as a method for systematically teaching specific teaching skills to students (Allen and Ryan, 1969). Microteaching was later incorporated into more comprehensive teacher training packages called "minicourses" by staff at the Far West Educational Laboratory (Borg, 1970). Closely related to these developments was the development of protocol and simulation 
materials (Cruickshank, 1984), systematic classroom observation systems (Simon and Boyer, 1967), and models of skill training (Joyce, Weil, and Wald, 1974).

All of these developments caused a great deal of controversy in the teacher education community. A vast, quickly emergent literature raised several major criticisms of the general orientation. One challenge as mentioned above, came from those who questioned the empirical validity of the "knowledge base" upon which these programs rested. Some criticized the methods that had been used in conducting the studies through which competencies were identified, but retained faith that improved research would overcome existing validity problems (Gage, 1970). Others questioned whether the complex and uncertain nature of teaching would ever enable these problems to be overcome through research (Tom, 1980) or argued that to attempt to do so, would limit our conception of teaching to "telling" (Broudy, 1973).

A second major line of protest against the C/PBTE movement came from "humanistic" educators such as Art Combs and his colleagues at the University of Florida. This critique focused on the assumptions of the behavioristic psychology underlying most examples of the approach. Combs (1972) even went so far as to argue that "requiring a teacher education program to define precisely the behaviors it hopes to produce may be the surest way to destroy the effectiveness of its products" (p. 288).

A third major critique of the C/PBTE movement came from those such as Apple (1972) and Nash and Agne (1971) who criticized the conservative political tendencies that were thought to be associated with the approach. By basing the specification of competencies on current conceptions of the teacher's role in a system that was thought to be in need of fundamental reform, it was argued that $\mathrm{C} / \mathrm{PBTE}$ necessarily undermined the reconstructionist ideals of many teacher educators and served to legitimate the status quo in school and society.

Despite the low rate of implementation of C/PBTE in teacher education programs across the United States, the social efficiency tradition has emerged once again in the current debates on teacher education reform, this time under the label of "research-based teacher education." Many current proposals for the reform of teacher education (e.g., The Holmes Group, 1986) have argued that the past decade of research on teaching has produced a "knowledge base" that can form the foundation for a teacher education curriculum. ${ }^{6}$ According to Berliner (1984), "We have only recently developed a solid body of knowledge and a fresh set of conceptions about teaching on which to base teacher education. For the first time, teacher education has a scientific foundation" (p. 94).

Feiman-Nemser (1990) has described two ways in which the social efficiency perspective has

\footnotetext{
${ }^{6}$ For example, in Tomorrow's Teachers (Holmes Group, 1986) it is concluded that "within the last twenty years ... the science of education promised by Dewey, Thorndike, and others at the turn of the century has become more tangible" (p. 52).
} 
been interpreted by contemporary teacher education reformers. First, she describes a technological version in which the intent is to teach prospective teachers the skills and competencies that research has shown to be associated with desirable pupil outcomes. This narrow interpretation is basically a reemergence of a behavioristic version of C/PBTE. Joyce and Showers's (1984) work with the development of procedures for skill training is cited by Feiman-Nemser (1990) as an example of this trend.

A second contemporary trend in the application of the findings of research on teaching to the design of teacher education curricula described by Feiman-Nemser (1990) is one in which the findings of research are used by teachers as "principles of procedure" within a broader process of decision making and problem solving. Advocates of this deliberative orientation to the use of research on teaching to improve teacher education argue that the reality of teaching demands an approach to teacher preparation which reflects the complex and uncertain nature of the work. The crucial task from this point of view is to foster teachers' capabilities to exercise judgment about the use of teaching skills:

Because they view good teaching as good deliberation, their concern is not that teachers follow a set of rules, which could never account for all circumstances anyway, but rather that teachers view teaching as a process of constantly making choices about the means and ends-choices that can be informed by process product research, descriptive research, experience, intuition, and one's own values. (Zumwalt, 1982, p. 226)

The Teacher as Decision Maker teacher education program at Michigan State University is cited by Feiman-Nemser (1990) as an example of this cognitively oriented approach to the application of research findings to teacher education. Another contemporary example of this approach is certain aspects of the PROTEACH program at the University of Florida (Ross and Kyle, 1987). Unlike the earlier behavioristically based C/PBTE movement which drew exclusively on correlational or experimental process-product studies of teaching, the current versions of the social efficiency paradigm have also drawn upon recent descriptive studies of classrooms, research on teacher thinking (e.g., Clark, 1988) or, as in Hunter's tremendously popular work (Gentile, 1988), upon cause and effect relationships between teaching and learning which have allegedly been established in research on human learning and behavior.

Although many of the devices for systematically training prospective teachers in the use of specific teaching skills like microteaching, have disappeared from the literature, newer versions more compatible with the broader cognitive orientation of the approach have emerged to take their place such as Cruickshank's (1987) "Reflective Teaching" program and skill training through microcomputer simulations (Strang, Badt, and Kauftman, 1987). Despite the variations among social efficiency based approaches throughout the century, the common thread that ties them together is their reliance on the 
scientific study of teaching as the major source for determining the teacher education curriculum.

\section{The Developmentalist Tradition}

The third major tradition of reform in 20th century U.S. teacher education, the developmentalist tradition, has its roots in the child study movement initiated by G. Stanley Hall and others near the turn of the century. According to Kliebard (1986), the most distinguishing characteristic of this tradition is the assumption that the natural order of the development of the learner provides the basis for determining what should be taught both to pupils in the public schools, and to their teachers. This natural order of child development was to be determined by research involving the careful observation and description of children's behavior at various stages of development. The most pressing need argued Lucy Sprague Mitchell (1931), founder of Bank Street College of Education, was "a scientific study of children's behavior as conditioned by the stage of their development and planning of a school environment upon the basis of such a study of growth" (p. 254).

In the early part of the century this tradition was most visible in the efforts of the "Bohemian progressives" $^{17}$ to prepare teachers to teach in the new child oriented progressive schools which were springing up all over the country. It is to this work that Vito Perrone (1989) refers when he writes about the progressive tradition in U.S. teacher education. These advocates of what was often referred to as the "new" or "modern" education were often very critical of the failure of regular teacher education institutions to supply them with creative and imaginative teachers who had a clear understanding of the developmentalist philosophy and children's patterns of growth and development. For as Pollitzer (1931) argued, only teachers imbued with a thorough understanding of that philosophy and a deep feeling for it can interpret its ideals in practice" (p. 247).

One critical element in these early developmentalist ideas about teacher education was that teachers for progressive schools must be educated in the same kind of supportive and stimulating environment that they were expected to provide for children. Advocates of new "student-centered" teacher education institutions were often very critical of the mechanical methods they felt were used in most teacher education institutions because they felt that mechanical methods in teacher preparation led to mechanical and passionless teaching. ${ }^{8}$

\footnotetext{
${ }^{7}$ Cowley (1934) discusses two segments of the progressive education movement that existed in the early part of the century: The Bohemian segment which involved a revolt of individuals against puritan restraint, and a radical element which involved a social revolt against the evils of capitalism. Cremin's (1961) discussion of the sentimentalists and radicals in the progressive education movement is also relevant to this distinction.

${ }^{8}$ The title of Margaret Pollitzer's (1931) paper "Growing Teachers for Our Schools" is very descriptive of the sentiments of these critics of conventional methods of teacher education.
} 
Still we go on preparing these young teachers of tomorrow by fifteenth century methods to achieve twentieth century aims. We continue to treat these youthful human souls as if they were machines; we polish the cogs with academic brick dust and the kelp of pedagogic taboos; we set them into working order, and in good, oiled, and empty futility we attempt to start these immortal locomotives. ... . We cultivate these young teachers' abilities but we give them no fire.... Their chief lack when we send them out to a completely irrational world for which we have prepared them in a wholly rational fashion is a flaming purpose. (Stroh, 1931, p. 260)

According to Perrone (1989), three central metaphors were associated with early manifestations of this progressive/developmentalist tradition in teacher education: (a) the teacher as naturalist, (b) the teacher as artist, and (c) the teacher as researcher. The teacher-as-naturalist dimension of the movement stressed the importance of skill in the observation of children's behavior and capability in building a curriculum and classroom environment that are consistent with patterns of child development and children's interests. Classroom practice was to be grounded in close observation and study of children in natural settings or on a literature that grew out of such study. Educating prospective teachers to conduct observations and to learn from and plan activities for children on the basis of their observations were key features in developmentalist proposals for teacher education reform.

The teacher-as-artist aspect of the developmentalist tradition had two dimensions. On the one hand, the artist teacher, who has a deep understanding of the psychology of child development, is able to excite children about learning by providing them with carefully guided activities in a rich and stimulating learning environment. To do this however, the teacher needs to be a wide awake and fully functioning person in touch with his or her own learning. A common developmentalist proposal was to provide prospective teachers with a variety of experiences in dance, creative dramatics, writing, painting, and storytelling so that they would be able to exemplify for their students an inquiring, creative, and openminded attitude. The comments of the director of one progressive school about the qualities needed for successful teaching illustrate the stress that was often placed on the personal and artistic development of the teacher in this tradition and also the influence of Freudianism on child-centered pedagogy in the 1920s.

I do not see how anyone can teach in a progressive school who is not a real person and who has not lived some sort of interesting, full life, or who is not living such a life. If one has amounted to something and is living life to the full, I have found little difficulty in giving the techniques necessary to make an excellent teacher, provided it is in the person. Such a one, who has an interest in life and is well balanced and emotionally free, has usually, by the very fact of his interest acquired the necessary sort of information and continues to keep it up. I should think that the courses for teachers would include dancing and physical education to relieve physical inhibitions; plenty of social contacts 
with life and persons of the opposite sex to relieve emotional inhibitions; a great deal of dramatic work and expression to free the teacher from self consciousness; and the discovery of some vital interest in the teacher's life and a pursuit of that interest as far as possible during the years at normal school.... Some of my best teachers have never been trained at all but have lived in a world of reality. (Bonser, 1929, p. 116)

The third guiding metaphor in the developmentalist tradition in teacher education was the teacher as researcher. Here the focus was on fostering an experimental attitude toward practice on the part of the teacher. Child study was to become the basis for teachers' inquiries, and teacher educators were to provide instruction to prospective teachers about how to initiate and sustain ongoing inquiries in one's own classroom about the learning of specific children. Lucy Sprague Mitchell's (1931) summary of the aims of the Cooperative School for Student Teachers illustrates the importance placed upon the development of an experimental attitude toward practice and its relationship to the artistic and naturalistic themes:

Our aim is to turn out teachers whose attitude toward their work and toward life is scientific. To us, this means an attitude of eager, alert observation; a constant questioning of old procedure in light of new observations; a use of the world, as well as of books, as source material; an experimental openmindedness, an effort to keep as reliable records as the situation permits, in order to base the future upon accurate knowledge of what has been done. Our aim is to equally turn out students whose attitude toward their work and toward life is that of the artist. To us this means an attitude of relish, of emotional drive, a genuine participation in some creative phase of work, and a sense that joy and beauty are legitimate possessions of all human beings, young and old. If we can produce teachers with an experimental, critical, and ardent approach to their work, we are ready to leave the future of education to them. (p. 251) ${ }^{9}$

Other than the Cooperative School for Student Teachers and subsequent work at Bank Street College and a few other institutions such as Milwaukee State Teachers College (Ayer, 1931), one does not find the overall transformation of mainstream teacher education that was intended by the childcentered progressives. An apprenticeship system has been and continues to be a major way in which the developmentalist philosophy is awakened in prospective teachers (Beatty, 1933).

During the late 1960s and early 1970s when child-centered pedagogy and "open education" once again received widespread attention in the United States, a number of experimental teacher

\footnotetext{
${ }^{9}$ Also quoted in Perrone (1989, p. 135). The Cooperative School for Student Teachers was a joint venture between the Bureau of Educational Experiments (the forerunner of Bank Street College) and eight progressive schools. The teacher education curriculum included practicum work in the progressive schools, and seminar, field, and studio work in New York City.
} 
education programs were initiated that resembled those of the child-centered progressives of earlier years. Crook (1974) analyzed four programs of this later era which sought to translate the assumptions underlying the "open education" movement into a teacher education curriculum. These were the Center for Teaching and Learning at the University of North Dakota, the American Primary Experimental Program at the University of Vermont, the Educational Program for Informal Classrooms at Ohio State, and the Integrated Day Program at the University of Massachusetts. Despite the differences that she found among these programs, Crook (1974) identified a number of developmentalist themes they all shared:

A commitment to involvement in one's own learning, an active approach to learning in terms of direct experience with materials, an encouragement of children's communication and prospective teachers' communication with children using skills of observing, reading, speaking, and writing; early field experiences, offerings in the expressive arts as well as in academic areas, and an understanding of children's development which reflects the writings of Jean Piaget. (p. 1)

About this same time, several other versions of the developmentalist tradition emerged in the literature. For example, Art Combs and his colleagues at the University of Florida received a lot of attention for their "humanistic" teacher education program (Combs, Blume, Newman, and Wass, 1974). Their notion of "self as an instrument" (that a good teacher is fundamentally a person striving to fulfill himself or herself), strongly resembles the earlier emphasis by Lucy Sprague Mitchell and her contemporaries on the teacher as artist. Another prominent developmentally oriented program of this period was the "Personalized Teacher Education Program" at the University of Texas which was grounded in Fuller's $(1972,1974)$ studies of teachers' concerns. Attempts were made to conduct this program in a manner so that the curriculum of the program addressed students' concerns as they experienced them. The assumption was that if the program was conducted in accordance with the developmental needs of students that the students would progress through various "stages of concerns" toward maturity as a teacher.

One of the most prominent contemporary examples of a developmentalist approach to teacher education is the Developmental Teacher Education Program at the University of California-Berkeley. This two-year graduate program culminating in a master's degree, was initiated by a small group of faculty who were dissatisfied with the limited emphasis given to knowledge of human development in teacher education programs (Amarel, 1988). This program, which is a clear example of the developmentalist emphasis on teacher as naturalist, is guided by the view that a grounded understanding of developmental principles is the best preparation for teaching. Students are exposed in their courses to theories of cognitive, social, moral, and language development and then focus in various practicums on 
the application of developmental principles to the teaching of mathematics, science, and literacy. In recent years the program has shifted from an application of content-free developmental principles to a concern with the development of domain specific knowledge within each of the basic school subjects (Ammon and Black, 1988).

\section{The Social Reconstructionist Tradition}

The fourth and final tradition in U.S. teacher education, the social reconstructionist tradition, defines both schooling and teacher education as crucial elements in a movement toward a more just society. According to Kliebard (1986), this tradition

derived its central thrust from the undercurrent of discontent about the American economic and social system... and saw curriculum as the vehicle by which social injustice would be redressed and the evils of capitalism corrected. This "undercurrent" existed in the 1920's and before and emerged in the 1930's. (p. 183)

A critical mass of influential and socially conscious progressives was located at Teachers College, Columbia, in the 1930s. Following the forceful articulation of the reconstructionist position by Counts (1932) in Dare the School Build a New Social Order, in which teachers were challenged to reach for political power and lead the nation to socialism, ${ }^{10}$ this reform perspective continued to be expressed and debated in the John Dewey Society for the Study of Education, ${ }^{11}$ and in the pages of The Social Frontier from 1934-1939 and its successor The Frontiers of Democracy from 1939-1943 (Bowers, 1969). This tradition, which was given strength by an economic depression, and by widespread social unrest, stressed the role of the school allied with other progressive forces, in planning for an intelligent reconstruction of U.S. society where there would be a more just and equitable distribution of the nation's wealth and where the "common good" would take precedence over individual gain. Given the vast number of changes wrought by science and technology, these "frontier educators" argued that it was the task of education "to prepare individuals to take part intelligently in the management of conditions under which they will live, to bring them to an understanding of the forces which are moving, and to equip them with the intellectual and practical tools by which they can themselves enter into the direction of these forces" (Kilpatrick, 1933, p. 71).

One of the major issues of debate among social reconstructionists was the degree to which

\footnotetext{
${ }^{10}$ Although collective ownership of the means of production was not essential to all social reconstructionists, most felt that at least the private economy must be regulated to help ensure full employment, economic opportunity, and adequate income for a fair standard of living (Stanley, 1985).

${ }^{11}$ Now the National Society for the Study of Education.
} 
teachers and teacher educators should consciously indoctrinate their students with socialist and collectivist values or rely on the methods of experimentalism and reflective inquiry to lead to social improvements. Counts (1932) was representative of those who argued for deliberate indoctrination of socialist values and ideas. In Dare the School Build a New Social Order he argued that given the inevitable partisanship of all educational activity and the dominance of capitalistic and individualistic values in all aspects of society, it is necessary for the teacher consciously to foster ideas and values supportive of the new social order. Holmes (1932) of Harvard and Bode (1935) of Ohio State are among those who rejected the notion that the school should be used to promote a previously determined social program. They placed their emphasis on cultivating students' ability to think critically about the social order.

Because the teaching profession was being asked by the "frontier educators" to assume a leadership role in the reconstruction of the American society, teacher education was viewed as playing a key role in the process.

The duty of the teachers colleges is thus clear. They must furnish over a period of years a staff of workers for the public schools who thoroughly understand the social, economic, and political problems with which this country is faced who are zealous in the improvement of present conditions and who are capable of educating citizens disposed to study social problems earnestly, think critically about them, and act in accord with their noblest impulses. (Brown, 1938, p. 328)

If teachers were to fulfill their role in social reconstruction however, teacher education would have to be reconstructed. In The Educational Frontier Kilpatrick (1933) and his colleagues, who included John Dewey, criticized traditional forms of teacher education for their emphasis on technique divorced from consideration of broader purposes, and called for a new social emphasis in the preparation of teachers where the stress would be on helping prospective teachers develop an adequate social and educational philosophy and "a zeal for the betterment of our common civilization" (p. 270). This development of a thoughtful orientation among prospective teachers about education and society was thought to be critical to the ability of teachers to lead the intelligent redirection of the social order.

More than anything else, so far as importance goes, does education mean the building of the life outlook ... the life outlook includes and orders everything else. . . Techniques and procedures become then subordinate, always so, to the general aims we set up for life and education.... Professional education must thus hold as its central and dominating feature the building of an inclusive and criticized outlook upon life and education. No step in the educative process can be weighed or judged except in the light of such a point of view, itself always growing as each new problem is most thoughtfully faced. The building and use of a philosophy of education thus becomes the key aim in 
professional education. (pp. 261-262)

Unlike many contemporary reconstructionist plans for teacher education which focus exclusively on what needs to be done to develop social consciousness and reform capabilities among prospective teachers, these earlier "frontier educators" recognized the dominant tendency toward conformity among the "teachers of teachers" and focused some of their efforts on awakening social consciousness among teacher educators.

In the education of teachers probably no one factor is more important than the social attitude of the faculty of the professional institution. In general social outlook and attitude ... the staff of our ordinary normal school or teachers' college is only too often severely lacking. A more adequate social outlook is an absolute necessity if prospective teachers are to catch the social vision. The socially unenlightened teaching too often found in the ordinary college or normal school can hardly have any other result than turning out teachers ignorant of our social situation and with no intelligent concern about it. We must then, as fast and as far as is humanly possible, bring it about that all members of the professional staff hold an intelligent and positive social outlook. . . . How to effect a new attitude within the professional school is no simple matter. One chief hope must lie in the work of the greater schools where the staff members of the lesser professional schools are prepared. .. . Each staff member should be encouraged to know first hand how the less favored among us live and feel. First-hand contacts carry greater potency. We can easily disregard the needs of those we do not know. In every possible way we must work for the more intelligently social outlook within the staff of our teacher preparing institutions. Without this, we can hardly hope for socially prepared teachers. (Kilpatrick et al., 1933, p. 266)

Two prominent early examples of efforts to apply the proposals of these radical progressives to teacher education were New College, an experimental and demonstration teacher education program at Columbia Teachers College from 1932-1939 and the emergence of an integrated social foundations component in teacher education programs. New College was designed to serve two major purposes: (a) to prepare "first-rate" elementary and secondary teachers and (b) to serve as a teacher education laboratory for those graduate students who would staff the teacher colleges of the nation.

The New College experiment represented a conscious effort to apply to teacher education the idea that teachers could be prepared to be leaders of societal reconstruction. The college's first announcement, quoted from Count's (1932) manifesto, reminded prospective teachers that "it is the peculiar privilege of the teacher to play a large part in the development of the social order of the next generation." (Cremin, Shannon, and Townsend, 1954, p. 222). Important elements of the New College experience were its integrating seminars, problems-based curriculum, and the firsthand experiences that 
were offered to students with various aspects of community life. The New College faculty held that "a major task of professional preparation is the enlargement of the student's range of interest and the deepening of his insight into basic problems of human living so that he may see his specific job in terms of larger social needs" (New College, 1936, p. 30).

The New College curriculum provided students with various opportunities for contact with life that would contribute to this development of a social outlook. All students were expected to develop skills of community planning, living, and leadership by spending at least a summer living and working on a student operated farm in western North Carolina. They were also required to work in industry for at least a summer, and to participate in numerous field trips that involved them with various cultural, and commercial opportunities in New York City.

Consistent with this emphasis on the value of direct experience in a teacher's education, the faculty constantly attempted to foster political activity among the students. For example, in 1937, the director announced the establishment of two scholarships that would be given to the two students who "go the furthest beyond academic neutrality in active participation in life outside the walls of the university" (Cremin, Shannon, and Townsend, 1954, p. 226). Many of the assemblies of students and faculty over the years became forums for the debate of political issues. Limbert (1934), in describing important happenings at the college during one four month period, reported a variety of activities that were consistent with the emphasis on developing students' abilities to take an intelligent stand on important economic and political issues. According to Limbert, the faculty was determined that no one be allowed to graduate from this teacher education program who was politically illiterate or indifferent:

The holding of several anti-war meetings and the selection of representatives to a university conference, where drastic action was taken looking toward the divorcing of the university from the war system. An assembly of the entire student body and staff to hear a proposal, presented by one of the professors, for the formation of a new movement for the reconstruction of American society, revolutionary in purpose, but fundamentally in accord with American traditions. A spirited criticism of this proposal by instructors and students, leading to a demand for additional assemblies for the discussion of similar proposals for social change. (p. 118) 
A second example of early attempts to apply the social reconstructionist agenda to teacher education was the development, also at Columbia Teachers College, of the social foundations of education as a component of a teacher education program. According to Cohen (1976), Rugg and Kilpatrick spearheaded in 1934-1935 "the most famous and influential innovation in American teacher education in the twentieth century" (p. 31), the initiation of the two-semester course Education 200F, Social Foundations of Education. According to Rugg (1952), the foundations of education, with its focus on the fundamental problems of the school, the society, and the culture, would aid in the development of a social and educational philosophy by prospective teachers that would enable them to assume a leadership role in the making of educational policy. According to the faculty who created the program, this coordination of focus among previously isolated disciplines, represents a significant shift from a mechanistic and atomistic outlook on life to an organic one (Borrowman, 1956). This effort toward developing an integrated social foundations approach was complemented by efforts to reconstruct the general education of teachers in a manner which broke down conventional subject matter boundaries, such as the efforts of Frank Baker at Milwaukee State Teachers College (Rugg, 1952, pp. 236-37).

Although Education 200F was never popular among many Teachers College faculty who maintained a commitment to a disciplined based education, the idea of social foundations courses spread to teacher education institutions throughout the United States. During the 1940s and 1950s, the leadership of the foundations movement in teacher education shifted to the University of Illinois where William Stanley, Kenneth Benne, B. Othaniel Smith, and Archibald Anderson formed the core of the social foundations group (Cohen, 1976). The newly developed social foundations components of teacher education programs and the "educationists" who taught them became the main targets for reformers in the academic tradition like Bestor, and Koerner who charged that the interdisciplinary focus of the foundations approach destroyed the integrity of the disciplines.

Another aspect of the social reconstructionist tradition has been the commitment, evident in several federally funded teacher education programs such as the National Teacher Corps and TTT, to alter social inequities by focusing on the improvement of educational conditions for children of the poor. Here it was hoped that the cycle of educational failure, poverty and despair for many rural and urban children could be broken through programs which specially prepared teachers and teacher educators to work in poverty schools. Among the contemporary examples of the social reconstructionist tradition in teacher education is Landon Beyer's work at Knox and Cornell colleges with the notion of "teacher education as praxis." Beyer (1988) describes his efforts to implement a "foundationally oriented" approach to teacher education that is guided by the normative principles of democracy, equality, and autonomy, and that is committed to the development of practical wisdom. A key to his efforts has been the examination by students of a variety of issues and situations from multiple and interdisciplinary 
perspectives. Another key is the intended union of reflective inquiry and practical action where students are given continuing opportunities to enact and then examine their ideas in practice. Beyer's commitment to the preparation of teachers who will be inclined toward and capable of contributing to the reconstruction of schools and society is clear: "Teacher education must be committed to the development of critically oriented, compassionate, and impassioned, reflective and socially engaged practitioners who can aid in the process of educational improvement and social change" (p. 185). Other contemporary proponents of a social reconstructionist view of teacher education include Ira Shor, Henry Giroux, and Peter McLaren. Shor (1987) for example, sets out an agenda for what he calls "egalitarian" teacher education. He proposes a number of themes that he feels need to permeate the teaching-learning process in teacher education programs if teacher education is to contribute to social change (e.g., dialogic teaching; cross cultural communication, and cultural literacy). Giroux and McLaren (1987), in contrast, propose a conceptual apparatus for thinking about teacher education as a democratizing or counterhegemonic force and teachers as "transformative intellectuals." According to Giroux and McLaren, if teacher education is to contribute toward a more just, humane, and equitable social order, then it needs to be viewed as a form of cultural politics based on the study of such themes as language, history, culture, and politics:

The project of doing a teacher education program based on cultural politics consists of linking critical social theory to a set of stipulated practices through which student teachers are able to dismantle and critically examine preferred educational and cultural traditions, many of which have fallen prey to instrumental rationality that either limits or ignores democratic ideals and principles. One of our main concerns focuses on developing a language of critique and demystification that is capable of analyzing the latent interests and ideologies that work to socialize students in a manner compatible with the dominant culture. We are equally concerned however, with creating alternative teaching practices capable of empowering students both inside and outside schools. (p. 173)

Other contemporary reconstructionist teacher education efforts in the United States include the work of Adler and Goodman (1986) who have used social studies methods courses to help prospective teachers develop curriculum analysis and development capabilities which will lead to more democratic school contexts; the "emancipatory" supervision methods developed by Gitlin and Smyth (1989); our own work in developing an inquiry-oriented student teaching program (Zeichner and Liston, 1987); many feminist inspired proposals for teacher education programs that seek to contribute toward the correction of gender inequities in schools and society (e.g., Maher and Rathbone, 1986); and proposals like those of Ginsburg (1988) which call for more political activity by teacher educators.

Beyond the common desire to prepare teachers who have critical perspectives on the 
relationships between schooling and societal inequities, and a moral commitment to correct those inequities through daily classroom and school activities, there is a great deal of variation among these contemporary proposals of social reconstructionist-oriented teacher educators. At various times the focus has been on the content of programs, the skills of critical analysis and curriculum development, the nature of pedagogical relationships between teachers and their pupils and between teacher educators and their students, or on the connections between teacher education and other political projects which seek to address the many instances of suffering and injustice in our society.

Despite the existence of all of these proposals, one of the most notable characteristics of contemporary social reconstructionism in teacher education is its marginal status in relation to teacher education programs in the United States. This marginal status is indicated in part, by the lack of examples of teacher education programs in which conceptual proposals are in the process of development. In several of the most prominent of these proposals (Giroux and McLaren, 1987; Ginsburg, 1988; and Shor, 1987) for example, there is not even a single reference to existing programmatic examples of the authors' proposals. This marginal status of the reconstructionist tradition in U.S. teacher education has been the case throughout most of the 20th century. According to Kliebard (1986), the social reconstructionist ideas of Counts and his contemporaries aroused the animosity of those on both the political left and right and had very little influence on school practices. Cremin (1988) concurs with this view and characterizes the social reconstructionist commentary as largely an academic discussion that has had very little influence outside its own inner circle. The marginal status of social reconstructionist reform proposals is one of the most critical issues that needs to be addressed by those within this tradition.

\section{The Reform Traditions and "Reflective Teaching"}

In our view, all contemporary proposals for the reform of U.S. teacher education reflect particular patterns of resonance with these four reform traditions. While we do not claim that this framework of reform traditions can capture the total essence of particular reform proposals, we do feel that it can potentially help teacher educators gain a deeper understanding of the fundamental differences in assumptions and goals underlying reforms that on the surface appear to be similar. "Reflective teaching" is a case in point.

In the last decade, concurrent with the rise of research on teacher thinking and the incorporation of aspects of the "cognitive revolution" into teacher education (Clark, 1988), "reflective teaching" and closely associated terms like "inquiry-oriented teacher education," "reflection-in-action," "teacher researchers", and "action research" have become fashionable throughout all segments of the U.S. 
teacher education community. ${ }^{12}$ Among the signs of this ascendancy are the two national conferences that have been held on the issue of reflective inquiry in teacher education (e.g., Clift, Houston, and Pugach, in press), the special issue of the Journal of Teacher Education (1989) that was recently devoted to "Critical Reflection in Teacher Education," the popularity of the descriptors "reflection" and "reflective teaching" at recent American Educational Research Association conferences and the recent proliferation of books and monographs on reflective practice in teaching and teacher education (e.g., Grimmett and Erickson, 1988; Posner, 1989; Waxman, Freiberg, Vaughn, and Weil, 1988).

It has come to the point now that we don't know very much at all about a practice if it is merely described as something aimed toward the development of reflective teachers. ${ }^{13}$ We agree with Calderhead's assessment that the full range of beliefs within the teacher education community about teaching, schooling, teacher education, and the social order has now been incorporated into the discourse about reflective practice (Calderhead, 1989). There is not a single teacher educator who would say that he or she isn't concerned about preparing teachers who are reflective, according to some set of criteria. The criteria which have been attached to reflective practice are so diverse however, that important differences between specific practices are masked by the use of the common rhetoric.

On the one hand, the recent work of teacher educators such as Cruickshank (1987) who has drawn upon Dewey (1933) for inspiration, gives us some guidance. The distinction which is often made between reflective and routine practice is not trivial and enables us to make some important qualitative distinctions among different teachers and teaching practices. ${ }^{14}$ Similarly, the enormously popular work of Schon $(1983,1987,1988)$ which has challenged the dominant technical rationality in professional education and argued for more attention to promoting artistry in teaching by encouraging "reflection in action" and "reflection on action" among teachers, also directs our attention to the preparation of particular kinds of teachers and not others. These generic approaches to reflective teaching lose their heuristic value however, after a certain point and eventually begin to hide more than they reveal. For example, after we have agreed that thoughtful teachers who reflect in and on action, are more desirable than thoughtless teachers who are ruled by tradition, authority, and circumstance, there are still many unanswered questions.

Neither Cruickshank (1987) nor Schon $(1983,1987,1988)$ have much to say about what it is

\footnotetext{
${ }^{12}$ See Calderhead (1989) and Martinez (1989) for a discussion of this same phenomenon in Canada, Australia, and the United Kingdom.

${ }^{13}$ Even the use of the term "critical reflection" does not necessarily reveal the particular commitments of teacher educators.

${ }^{14}$ According to Dewey (1933) reflective action entails "active persistent and careful consideration of any belief or supposed form of knowledge in light of the grounds that support it and the further consequences to which it leads" (p. 9). He distinguishes this from routine action which is guided primarily by the tradition and authority.
} 
that teachers ought to be reflecting about, the kinds of criteria which should come into play during the process (e.g., technical or moral), the degree to which teachers' reflections should incorporate a critique of the institutional contexts in which they work, the nature of the actions which fall within the range of "acceptable" practice, nor about the particular historical traditions out of which a particular line of work emerges. In some extreme cases, the reader is given the impression that as long as teachers reflect about something, in some manner, that whatever they decide to do is okay, since they have "reflected" about it. One of the reasons that these generic notions about reflection have been so popular is that they can be (and have been) employed by teacher educators of almost every ideological persuasion. Everyone can identify with them and they offend no one, except possibly those who would seek to control teachers' actions through external prescription. Despite the important distinctions between reflective and routine practice on the one hand (Dewey, 1933) and between technical rationality and an epistemology of practice (Schon, 1983) on the other, both of which affirm the value of teachers' practical knowledge, we do not think it makes much sense to attempt to promote or assess reflective practice in general (e.g., Boud, Keogh, and Walker, 1985; Kirby and Teddlie, 1989; Stout, 1989) without establishing some clear priorities for the reflection that emerge out of a reasoned educational and social philosophy. We do not accept the implication that exists throughout much of the literature that teachers' actions are necessarily "better" just because they are more deliberate and intentional (see Kennedy and Zeichner, 1989).

One way in which the reform traditions framework can play a useful role in enhancing the value of the reflective inquiry movement in teacher education for program development and policy making, is in helping to clarify the specific commitments which stand behind particular uses of the term reflection. We think that there is a world of difference between the academically oriented proposals of those like Shulman (1987), the developmentalist proposals of those like Duckworth (1987), the social efficiency oriented proposals of Berliner (1985) and out of the University of Florida (e.g., Ross and Kyle, 1987) ${ }^{15}$ and the social reconstructionist driven proposals of those like Beyer (1988) and ourselves (Liston and Zeichner, in press). Each of these lines of work directs teachers' reflections to particular aspects of teaching practice (e.g., the representation of subject matter, children's thinking, the social context, or to particular teaching strategies suggested by research on teaching). Each of these views of reflective practice establishes certain priorities about schooling and society which emerge out of a particular historical tradition and a coherent educational and social philosophy. None of them is sufficient by itself. None of them should be summarily dismissed as has become currently fashionable with regard to anything that can be linked to the social efficiency tradition.

\footnotetext{
${ }^{15}$ These examples are not intended to place particular individuals or programs solely within a single reform tradition. As a teacher education program PROTEACH is probably more developmentalist in character than anything else (Zeichner, 1988c). When Ross and her colleagues talk about helping teachers make intelligent use of teacher effectiveness research however, this is a clear example of a social efficiency oriented practice.
} 
This is not to say that we should aim for some sort of eclectic combination of traditions within particular teacher education programs which seeks to accommodate everyone and to offend none. The particular priorities which are established in teacher education programs about the issues raised in these varying interpretations of reflection are significant. For example, the ways in which social efficiency concerns are addressed in a developmentalist-oriented program are very different from the ways in which these same concerns would be addressed in a social reconstructionist-driven program. Ideological evenhandedness does justice to no tradition and only leads to further confusion. ${ }^{16}$

Our point is that the debate about reflection and other contemporary reform proposals needs to take place at a very specific level where the different traditions and commitments associated with particular proposals are exposed for analysis and critique. The reform traditions offer one possibility for informing this debate, ${ }^{17}$ a possibility that would bring some historical perspective into the discussion.

One thing that we do not wish to further by attempting to clarify more sharply the priorities of particular reform proposals is the ideological insularity which currently plagues our field. In our view this insularity continues to be one of the most serious impediments to the improvement of teacher education in the United States. The common pattern has been and continues to be for various subcommunities of teacher educators to operate with relative independence of one another. There continues to be very little cross-fertilization of ideas across traditions of practice, as members of the various subcommunities typically read, discuss, debate and cite work only within a particular reform tradition and frequently dismiss and/or ignore ideas outside of their own particular subcommunity (see Zeichner, 1983). In offering the reform traditions framework as a possibility for structuring aspects of the current debate in U.S. teacher education, we hope that the use of this framework will facilitate more discussion and vigorous debate across as well as within particular traditions. As a first step however, we need to move beyond the current situation in which important differences in our commitments and passions are hidden from view by the use of popular slogans.

\footnotetext{
${ }^{16}$ In our view the recently issued AACTE sponsored Knowledge Base for Beginning Teachers (Reynolds, 1989) is guilty of this ideological evenhandedness. See Ott, Zeichner, and Price (in press) for further discussion of this issue.

${ }^{17}$ Other approaches to clarifying the differences among different conceptions of reflective teaching practice such as Tom's (1985) will also promote the kind of debate and discussion we would like to support.
} 


\section{References}

Adler, S. and Goodman, J. (1986). Critical theory as a foundation for methods courses. Journal of Teacher Education, 37, 4, 2-8.

Allen, D. and Ryan, K. (1969). Micro teaching. Reading, MA: Addison-Wesley Publishing Co.

Amarel, M. (1988). Developmental teacher education. In Dialogues in teacher education (Issue paper 88-4). East Lansing, MI: National Center for Research on Teacher Education.

Ammon, P. and Black, A. (1988). A response to M. Amarel. In Dialogues in teacher education (Issue paper 88-4). East Lansing, MI. National Center for Research on Teacher Education.

Apple, M. (1972). Behaviorism and conservatism: The educational views in four of the "systems" models of teacher education. In B. Joyce and M. Weil (Eds.) Perspectives for reform in teacher education. Englewood Cliffs, NJ: Prentice Hall.

Atkin, J. M. and Raths, J. D. (1974). Changing patterns of teacher education in the U.S. Urbana, IL: University of Illinois School of Education.

Ayer, A. (1931). Freedom for the student teacher. Progressive education, 8, 3, 256-260.

Ball, D. and McDiarmid, G. W. (1990). The subject matter preparation of teachers. In W. R. Houston (Ed.) Handbook of research on teacher education. New York: Macmillan.

Baptiste, H. P.; Baptiste, M. and Gollneck, D. (1980). Multicultural teacher education: Preparing educators to provide educational equity. (Vol. 1) Washington, DC: American Association of Colleges of Teacher Education.

Beatty, W. (1933). Training the teacher for the new school. Progressive Education, 10, 5, 248-253.

Berliner, D. (1984). The half-full glass: A review of research on teaching. In P. Hosford (Ed.) Using what we know about teaching. Alexandria, VA: Association of Supervision and Curriculum Development.

Berliner, D. (1985). Laboratory settings for the study of teacher education. Journal of Teacher Education, 2-8.

Bestor, A. (1953). Educational wastelands. Urbana: University of Illinois Press.

Bestor, A. (1956). The restoration of learning. New York: Alfred Knopf.

Beyer, L. (1988). Knowing and acting: Inquiry, ideology, and educational studies. London: Falmer Press. 
Bode, B. (1935). Dr. Bode replies. The Social Frontier, 2, 2, 42.

Bonser (1929). The training of teachers for the new education. Progressive education, 6, 111-121.

Borg, W. (1970). The minicourse. Beverly Hills, CA: Macmillan Educational Services.

Borrowman, M. (1956). The liberal and technical in teacher education. New York: Teachers College Press.

Borrowman, M. (1965). Liberal education and the professional preparation of teachers. In M. L. Borrowman (Ed.) Teacher education in the U.S.: A documentary history. New York: Teachers College Press.

Boud, D.; Keogh, R., and Walker, D. (1985). Promoting reflection in learning: A model. In Reflection: Turning experience into learning. London: Kogan Page.

Bowers, C. A. (1969). The progressive educator and the depression: The radical years. New York: Random House.

Broudy, H. (1973). A critique of PBTE. Washington, DC: American Association of Colleges of Teacher Education.

Cabello, B. and Dash, R. (1988). Programs for the recruitment, preparation and retention of teachers to work with diverse student populations. San Francisco: Far West Laboratory for Educational Research and Development.

Calderhead, J. (1989). Reflective teaching and teacher education. Teaching and Teacher Education.

Charters, W. W. and Waples, D. (1929). Commonwealth teacher training study.

Clark, C. (1988). Asking the right questions about teacher preparation: Contributions of research on teacher thinking. Educational Researcher, 17, 2, 5-12.

Clark, S. C. T. (1969). The story of elementary teacher education models. Journal of Teacher Education, 20, 3, 283-293.

Clifford, G. J. and Guthrie, J. W. (1988). ED school. Chicago: University of Chicago Press.

Clift, R.; Houston, W. R., and Pugach, M. (in press). Encouraging reflective practice: An examination of issues and exemplars. New York: Teachers College Press.

Cohen, S. (1976). The history of the history of American education. Harvard Educational Review, 46, 3, 298-330. 
Coley, R. and Thorpe, M. (1986). A look at the M.A.T. model of teacher education and its graduates: Lessons for today. Princeton, NJ: Educational Testing Service.

Combs, A. (1972). Some basic concepts for teacher education. Journal of Teacher Education, 22, 286-90.

Combs, A.; Blume, R.; Newman, A.; Wass, H. (1974). The professional education of teachers: A humanistic approach to teacher education.

Conant, J. (1963). The education of American teachers. New York: McGraw Hill.

Corwin, R. (1973). Reform and organizational survival: The Teacher Corps as an instrument of educational change. New York: Wiley-Interscience.

Counts, G. (1932). Dare the schools build a new social order? New York: The John Day Co.

Cowley, M. (1934). Exiles return. New York.

Cremin, L. (1953). The heritage of American teacher education. Journal of Teacher Education, 4, 2 , 163-170.

Cremin, L. (1961). The transformation of the school: Progressivism in American Education, 1876-1957. New York: Vintage Books.

Cremin, L. (1988). American education: The metropolitan experience 1876-1980. New York: Harper and Row.

Cremin, L.; Shannon, D.; and Townsend, M. E. (1954). A history of Teachers College Columbia University. New York: Columbia University Press.

Crook, P. (1974). A study of selected teacher training programs in the U.S. committed to a Philosophy of "open education". Unpublished Ph.D. dissertation. Syracuse University.

Cruickshank, D. (1984). Models for the preparation of America's teachers. Bloomington, IN: Phi Delta Kappa Educational Foundation.

Cruickshank, D. (1987). Reflective teaching. Reston, VA: Association of Teacher Educators.

Damerell, R. (1985). Education's smoking gun: How teachers colleges have destroyed education in America. New York: Freundlich Books.

Dewey, J. (1933). How we think. Chicago: Henry Regnery. 
Drummond, W. and Andrews, T. (1980). The influence of federal and state governments on teacher education. Phi Delta Kappan 97-99.

Duckworth, E. (1987). The having of wonderful ideas. New York: Teachers College Press.

Feiman-Nemser, S. (1990). Teacher preparation: Structural and conceptual alternatives. In W. R. Houston (Ed.) Handbook of research on teacher education. New York: Macmillan.

Fennema, E.; Carpenter, T. and Peterson, P. (in press). Teachers-decision making and cognitively guided instruction--A new paradigm for curriculum development. In K. Clements and N. F. Ellerton (Eds.) Facilitating change in mathematics education. Geelong, Australia: Deakin University Press.

Flexner, A. (1930). Universities: American, English, German. Oxford, England: Oxford University Press.

Fuller, F. (1972). Personalizing teacher education. Austin, TX: Research and Development Center for Teacher Education.

Fuller, F. (1974). A conceptual framework for a personalized teacher education program. Theory into practice, 13, 2, 112-122.

Gage, N. (1970). Teacher effectiveness and teacher education. Palo Alto, CA: Pacific Books.

Gage, N. and Winne, P. (1975). Performance-based teacher education. In K. Ryan (Ed.) Teacher Education. Chicago: University of Chicago Press.

Gay, G. (1986). Multicultural teacher education. In J. Banks and J. Lynch (Eds.) Multicultural education in western societies. New York: Praeger, 154-177.

Gentile, J. R. (1988). Instructional improvement: Summary and analysis of Madeline Hunter's essential elements of instruction and supervision. Oxford, $\mathrm{OH}$ : National Staff Development Council.

Ginsburg, M. (1988). Contradictions in teacher education and society: A critical analysis. New York: Falmer Press.

Giroux, H. and McLaren, P. (1987). Teacher education and the politics of engagement: The case for democratic schooling. In M. Okazawa-Ray; J. Anderson and R. Traver (Eds.) Teaching, teachers and teacher education. Cambridge, MA: Harvard Educational Review. pp. 157-182.

Gitlin, A. and Smyth, J. (1989). A dialogical approach to understanding: Horizontal evaluation. In Teacher evaluation: Educative alternatives. New York: Falmer Press. 
Gollnick, D. (1978). Multicultural education in teacher education: The state of the scene. Washington, DC: American Association of Colleges of Teacher Education.

Grant, C. and Koskella, R. (1986). Education that is multicultural and the relationship between preservice campus learning and field experiences. Journal of Educational Research, 79, 197-203.

Grant, C. and Secada, W. (1990). Preparing teachers for diversity. In W. R. Houston (Ed.) Handbook of research on teacher education. New York: Macmillan.

Grimmett, P. and Erickson, G. (Eds.) (1988). Reflection in teacher education. New York: Teachers College Press.

Heath, R. W. and Nielson, M. (1974). The research basis for performance-based teacher education. Review of Educational Research, 44, 463-84.

Hendrick, I. (1967). Academic revolution in California. Southern California Quarterly, 49, $(2,3,4)$ 127-166; 253-295; 359-406.

Herbst, J. (1989). And sadly teach: Teacher education and professionalization in American culture. Madison: University of Wisconsin Press.

Holmes, H. (1932). The teacher in politics. Progressive Education, 4, 414-418.

Holmes Group (1986). Tomorrow's teachers. East Lansing, MI: The Holmes Group Inc.

Howey, K. and Zimpher, N. (1989). Profiles of preservice teacher education. Albany: State University of New York Press.

Imig, D. (1986). Outrage in Texas. AACTE Briefs, 9, 1, 2, 12.

Johnson, W. (1987). Empowering practitioners: Holmes, Carnegie, and the lessons of history. History of Education Quarterly, 27, 2, 221-240.

Journal of Teacher Education, (1989). Critical reflection in teacher education: Practices and problems, $40,2$.

Joyce, B. (1975). Conceptions of man and their implications for teacher education. In K. Ryan (Ed.) Teacher education. Chicago: University of Chicago Press.

Joyce, B. and Showers, B. (1984). Power for staff development through research on training. Washington, DC: Association for Supervision and Curriculum Development.

Joyce, B.; Weil, M. and Wald, R. (1974). Models of teaching in teacher education. An evaluation of 
instructional systems. Interchange, 4, 47-73.

Joyce, B.; Yarger, S. and Howey, K. (1977). Preservice teacher education. Palo Alto, CA: Booksend Laboratory.

Kennedy, M. and Zeichner, K. (1989). Ken Zeichner reflecting on reflection. Colloquy, 2, 2, 15-21.

Keppel, F. (1986). A field guide to the land of teachers. Kappan, 67, 18-23.

Kilpatrick, W. (Ed.) (1933). The educational frontier. New York: The Century Co.

Kirby, P. and Teddlie, C. (1989). Development of the reflective teaching instrument. Journal of Education Research, 22, 4, 46-51.

Kirk, D. (1986). Beyond the limits of theoretical discourse in teacher education: Towards a critical pedagogy. Teaching and Teacher Education, 2, 155-167.

Kliebard, H. (1975). The rise of scientific curriculum making and its aftermath. Curriculum Theory Network, 5, 1, 27-38.

Kliebard, H. (1986). The struggle for the American curriculum, 1893-1958. Boston: Routledge and Kegan Paul.

Koerner, J. (1963). The miseducation of American teachers. Boston: Houghton Mifflin.

Lanier, J. (1986). Research on teacher education. In M. Wittrock (Ed.) Third handbook of research on teaching. New York: Macmillan.

Limbert, P. (1934). Political education at New College. Progressive Education, 11, 2, 118-124.

Liston, D. and Zeichner, K. (in press). Teacher education and the conditions of schooling. New York: Routledge.

Lynd, A. (1953). Quackery in the public schools. Boston: Little Brown.

MacIntyre, A. (1988). Whose justice? Which rationality? Notre Dame, IN: University of Notre Dame Press.

Maher, F. and Rathbone, C. (1986). Teacher education and feminist theory: Some implication for practice. American Journal of Education, 94, 214-235.

Martin, J. R. (1987). Reforming teacher education: Rethinking liberal education. Teachers College Record, 88, 3, 406-410. 
Martinez, K. (1989). Critical reflections on critical reflection in teacher education. Paper presented at the Fourth National Conference on the Practicum in Teacher Education, Rockhampton, Australia.

McDonald, F. (1973). Behavior modification and teacher education. In C. Thoresen (Ed.) Behavior modification in Education. Seventy-second yearbook of the National Society for the Study of Education. Chicago: University of Chicago Press.

Mitchell, L. S. (1931). Cooperative schools for student teachers. Progressive Education, 8, 251-255.

Nash, R. and Agne, R. (1971). Competency in teacher education: A prop for the status quo. Journal of Teacher Education, 22, 2, 147-156.

National Center for Education Statistics (1977). The State of teacher education. Washington, DC: NCES.

New College (1936). Teachers College Record, 38 1, 1-73.

Ott, D.; Zeichner, K. and Price, G. (in press). Research horizons in teacher education and the quest for a knowledge base in early childhood education. In B. Spodek and O. Saracho (Eds.) Yearbook in early childhood education. New York: Teachers College Press.

Perrone, V. (1989). Teacher education and progressivism: A historical perspective. In Author Working Papers: Reflections on teachers, schools and communities. New York: Teachers College Press.

Pollitzer, M. (1931). Growing teachers for our schools. Progressive Education, 8, 3, 247-250.

Posner, G. (1989). Field experience: Methods of reflective teaching (2nd edition). New York: Longman.

Powell, A. (1976). University schools of education in the twentieth century. Peabody Journal of Education, 54, 1, 3-20.

Provus, M. (1975). The grand experiment: The life and death of the TTT program as seen through the eyes of its evaluators. Berkeley: McCutchan.

Reynolds, M. (Ed.) (1989). Knowledge base for the beginning teacher. New York: Pergamon Press.

Ross, D. and Kyle, D. (1987). Helping preservice teachers learn to use teacher effectiveness research. Journal of Teacher Education, 38, 40-44.

Rugg, H. (1952). The teacher of teachers. New York: Harper and Brothers Publishers. 
Sandefur, W. S. and Nicklas, W. L. (1981). Competency-based teacher education in AACTE institutions: An update. Phi Delta Kappan, 62, 747-748.

Saxe, R. (1965). Evaluating the break through programs. Journal of Teacher Education, 16, 202-209.

Schneider, B. (1987). Tracing the provenance of teacher education. In T. Popkewitz (Ed.) Critical studies in teacher education. New York: Falmer Press.

Schon, D. (1983). The reflective practitioner. New York: Basic Books.

Schon, D. (1987). Educating the reflective practitioner. San Francisco: Jossey Bass.

Schon, D. (1988). Educating teachers as reflective practitioners. In P. Grimmett and G. Erickson (Eds.) Reflection in teacher education. New York: Teachers College Press.

Schram, P.; Wilcox, S.; Lanier, P. and Lappan, G. (1988). Changing mathematical conceptions of preservice teachers. (Research Report No. 88-4). East Lansing, MI: National Center for Research on Teacher Education.

Shor, I. (1987). Equality is excellence: Transforming teacher education and the labor process. In M. Okazawa-Ray, J.; J. Anderson and R. Traver (Eds.) Teaching, teachers and teacher education. Cambridge, MA: Harvard Educational Review, pp. 183-203.

Shulman, L. (1986). Paradigms and research programs in the study of teaching. In M. Wittrock (Ed.) Third handbook of research on teaching. New York: Macmillian.

Shulman, L. (1987). Knowledge and teaching: Foundations of the new reform. Harvard Educational Review, 57, 1-22.

Simon, A. and Boyer, G. (1967). Mirrors for behavior. Philadelphia: Research for better schools.

Smith, W. (1980). The American Teacher Corps Programme. In E. Hoyle and J. Megarry (Eds.) Professional development of teachers. London: Nichols.

Stanley, W., Jr. (1985). Social reconstructionism for today's social education. Social Education, 49, 5, 384-389.

Stone, J. C. (1968). Break through in teacher education. San Francisco: Jossey Bass.

Stout, C. J. (1989). Teachers' views of the emphasis on reflective teaching skills during their student teaching. Elementary School Journal, 89, 4, 511-527.

Strang, H. R.; Badt, K. and Kauffman, J. (1987). Micro computer-based simulations for training fundamental teaching skills. Journal of Teacher Education, 38, 1, 20-26. 
Stroh, M. (1931). No title. Progressive Education, 8, 3, p. 260.

Sykes, G. (1984). Teacher education and the predicament of reform. In C. E. Finn.; D. Ravitch and R. Fancher (Eds.) Against mediocrity. New York: Holmans and Meier.

Tetreault, M. K. T. (1987). The scholarship on women and teacher education. Teacher Education Quarterly, 14, 2, 77-83.

Tetreault, M. K. and Braunger, J. (1989). Improving mentor teacher seminars: Feminist theory and practice at Lewis and Clark College. In J. DeVitis and P. Sela (Eds.) Building bridges for educational reform: New approaches to teacher education. Ames, Iowa: Iowa State University Press.

Tom, A. (1980). The reform of teacher education through research: A futile quest. Researchers College Record, 82, 1, 15-30.

Tom, A. (1984). Teaching as a moral craft. New York: Longman.

Tom, A. (1985). Inquiring into inquiry-oriented teacher education. Journal of Teacher Education, 36, $5,35-44$.

Travers, E. and Sacks, S. (1987). Teacher education and the liberal arts: The position of the Consortium for Excellence in Teacher Education. Swarthmore, PA: Swarthmore College.

Turney, C. (1977). Innovation in Teacher Education. Sydney, Australia: Sydney, University Press.

Uhler, S. (1987). Alternative paths to entry: New Jersey and elsewhere. Paper presented at the annual meeting of the American Educational Research Assosication, Washington, DC

Waxman, H. J.; Freiberg, J. C.; Vaughn, J. and Weil, M. (Eds.) (1988). Images of reflection in teacher education. Reston, VA: Association of Teacher Educators.

Wilson, S.; Shulman, L. and Richert, A. (1987). 150 different ways of knowing: Representations of knowledge in teaching. In J. Calderhead (Ed.) Exploring teachers' thinking. London: Cassell.

Woodring, P. (1957). New directions in teacher education. New York: Fund for the Advancement of Education.

Zeichner, K. (1983). Alternative paradigms of teacher education. Journal of Teacher Education, 34, 3-9.

Zeichner, K. (1988a). Understanding the character and quality of the academic and professional components of teacher education. East Lansing, MI: National Center for Research on Teacher 


\section{Education.}

Zeichner, K. (1988b). Learning from experience in graduate teacher preparation. In A. Woolfolk (Ed.) Research perspectives on the graduate preparation of teachers. Englewood Cliffs, NJ: Prentice Hall.

Zeichner, K. (1988c). University of Florida's PROTEACH. In Dialogues in teacher education, (Issue Paper 88-4). East Lansing, MI: National Center for Research on Teacher Education.

Zeichner, K. and Liston, D. (1987). Teaching student teachers to reflect. Harvard Educational Review, 57, 1, 1-22.

Zumwalt, K. (1982). Research on teaching: Policy implications for teacher education. In A. Lieberman and M. McLaughlin (Eds.) Policy making in education. Chicago: University of Chicago Press. 